\title{
Origins of the Public/Private Theory of Legal Systems
}

\section{Christian Turner}

Wherever people are present and acting together, we can find in the social glue between them the process we call law. It is not a written list of rules, the collected judgments of courts, or the decrees of a monarch. These things are the tools of law and the evidence of its practice, not law itself. Law is a process, the human-willed system of cause and effect that governs the evolution of the togetherness of those who choose to act together. It is a kind of inevitable source code on which a society runs, its output read and acted upon to yield one physical moment and then the next. ${ }^{1}$ Always being rewritten and contested, this intellectual wraith that is the law, this thing that exists only in our minds and is given form only by our actions and communications, this is the object of our study.

Is the process of law as unpredictable and varied as the distinct and random neuronal firings of peoples separated by oceans and millennia? Are there, instead, basic principles or a logic of law that is invariant among its instances? The word 'law' suggests its practice may be thought to have at least some kinship with the natural laws of our universe. Those 'laws' are also abstract understandings of the connections between causes and effects. Indeed, various legal philosophies have taken this similarity nearly to the point of identity. ${ }^{2}$ While most naturally associated with formalists, ${ }^{3}$ even the archetypal legal realist Arthur Corbin noted that both 'rules of physics and rules of law ... enable us to predict physical consequences and to regulate our actions accordingly. ${ }^{4}$ Taken to the extreme, the laws of the legal world just involve distinctive kinds of physical events and objects, in the same way that chemistry, biology, and ecology are all, ultimately, physics but have developed special methods, conclusions, and approximations concerning the complex physical processes within their domains.

'Law is the projection of an imagined future upon reality.' Robert M. Cover, 'Violence and the Word' (1986) 95 Yale Law Journal 1601 at 1604.

2 See, e.g., Thomas C. Grey, 'Langdell's Orthodoxy' (1983) 45 University of Pittsburgh Law Review 1 at 1632 (describing Langdellian legal science as analogous to the study of Euclidean geometry but with axioms capable of slow evolution).

3 See, e.g., Guido Calabresi, 'An Introduction to Legal Thought: Four Approaches to Law and to the Allocation of Body Parts' (2002) 55 Stanford Law Review 2113 at 2114-5.

4 Arthur L. Corbin, 'Jural Relations and Their Classification' (1921) 30 Yale Law Journal 226 at 227. Corbin continued, 'When the physical event that we are predicting is the conduct of a state agent, executive or judicial, acting for society, the rule that we are applying is called a rule of law; and with respect to the expected action of societal agents, our relations to our fellow men are commonly called legal (or jural) relations.' Corbin's suggestion could be taken as materialistic, that law is ultimately physics, and so as with the other sciences, our goal is to understand the principles that govern the evolution of such physical systems. This frees the legal thinker to bend conclusions to observations, liberating him or her from unexamined maxims, a key goal of realism. It also reclaims the mantle of science by cleverly reframing the objects responsive to scientific principles as human beings rather than legal data. At least as of his retirement, Corbin believed that while the sciences were, with respect to law, 'underlying disciplines,' law itself could not reach scientific conclusions. See Calabresi, 'An Introduction', 2121. 
We need not go that far. The law of a place is purely the product of human will. It can be contested, changed, incomplete, disastrous, ignored, or followed. ${ }^{5}$ Scientists attempt to induce and deduce the universal connections between cause and effect that exist independent of our own desires. Lawyers create and sever such connections, the causes of legal action and a society's responses to those causes, as it suits us. My goal in this chapter is not to deduce what law essentially is, a fruitless enterprise that misunderstands the possibilities of theoretical inquiry. Rather, I aim to explore the consequences of a few simple observations about human cooperation that can help us better understand what we are doing when we do law. I look not for axioms to which law must conform but to foundational decisions those who maintain legal systems inevitably must make, the structure those decisions necessarily impose, and the types of considerations that will bear on them.

My specific theory is that the practice of law in a society involves an unavoidable and fundamental division of authority over lawmaking and prosecution among various institutional types, characterised most basically by their public or private nature. ${ }^{6}$ Legal systems divide other kinds of questions among institutions, and both public and private institutions can come in far more specific flavours. Yet this very simple understanding yields a striking picture of legal systems, one that has a great deal of explanatory power and points us in fruitful directions when faced with more specific questions concerning a society's law. It vividly divides and clarifies law's traditional fields of study. It clearly identifies the distinctions between primary and secondary rules and helps to reveal the essential similarities and differences among the secondary rules of the various fields. Most importantly, it shows us just how much of legal discourse is constructed from very basic institutional competency arguments. By way of preview, the picture of law that the theory reveals is the following:

\begin{tabular}{|c|c|c|c|}
\cline { 3 - 4 } \multicolumn{2}{c|}{} & \multicolumn{2}{c|}{ Constitutional Law } \\
\cline { 3 - 4 } \multicolumn{2}{c|}{ Procedure } & Privately Created & Publicly Created \\
\hline \multirow{2}{*}{} & $\begin{array}{c}\text { Privately } \\
\text { Prosecuted }\end{array}$ & Contract Law & Tort Law \\
\cline { 2 - 4 } & $\begin{array}{c}\text { Publicly } \\
\text { Prosecuted }\end{array}$ & Parens Patriae & Criminal Law \\
\hline
\end{tabular}

To appreciate better what this picture is and why it is helpful, I will frame the summary of the public/private theory from the ground up. I will begin with a very elementary understanding of a public, showing its identification with the management of coercion, which I call law. Next, I will explore how a public must conduct the management of its coercive resources. Following Hart, this consists in using both primary and secondary rules but in a system which

5 See, e.g., H. L. A. Hart, The Concept of Law, second edition (Oxford: Clarendon Press, 1994), p. 187 ('[P]rescriptive laws may be broken and yet remain laws, because that merely means that human beings do not do what they are told to do; but it is meaningless to say of the laws of nature, discovered by science, either that they can or cannot be broken.').

6 I first advanced this theory in Christian Turner, 'Law's Public/Private Structure' (2012) 39 Florida State University Law Review 1003, and applied it again in Christian Turner, 'State Action Problems' (2013) 65 Florida Law Review 281. The former contains a far more detailed treatment of the theory and its applications than appears here. This chapter is intended both to summarise the theory, to motivate it philosophically, and to show its continuity with diverse jurisprudential approaches. 
is itself a union of information and institutions. Finally, I will discuss the basic public-private distinctions (plural) that naturally define the intuitive, institutional taxonomy of legal systems summarised in the chart above.

Because it is impossible to imagine law without a public, one would reasonably expect the distinction between a public and its lexical opposite, the private, to loom large in legal theory. Curiously, though, the distinction has been textually derided at the same time it has been subtextually and perhaps even subconsciously developed. No matter how frustrating these concepts are to identify and use, no matter how critical we might wish to be, the publicprivate distinction is inseparable from law itself. In the course of arriving at the publicprivate theory of legal systems, I will attempt to show how the germs of the theory have been laid by movements ordinarily thought hostile to the distinction.

The goal of developing a model from simple and uncontroversial assumptions is not only to produce a clarifying description. From the model's structural features, it is often possible to surmise particular principles of law deductively after the addition of context. For example, a rule concerning the unconscionability of private contracts might be derived from a more general principle of institutional competency applied to the particular institution of private, contracting parties. Where deduction does not fully settle the matter, that is, where more than one rule would seem to follow from a general, trans-substantive principle, we still gain from seeing the continuity of the unresolved problem with problems in other fields of law and, more practically, from the particular, contextual difficulties that are creating an ambiguous application of principle.

The social practice of cooperation is as multi-faceted as the human beings conducting it. An attempt to describe law's one, true nature is doomed to fail. Nevertheless, I aim to provide a simplifying but rich model of its practice. The model is itself neither purely descriptive nor normative in the narrow, doctrinal sense. It is instead an attempt to illuminate the largely inevitable, basic plan of our social source code. How can we most easily understand this complex set of human interactions? Yes, law has no singular essence, but there is at least this simple way of seeing its patterns: as repeated divisions of authority among public and private institutions.

\section{A Public and its Legal System}

This volume generally concerns the most fundamental elements of the abstract process that is the law: the public and the private. From the mere assumption of cooperation, we can find the former, the public, and that is where I begin. People transcend the mere plural of person and become a public only when they desire to do at least some minimal set of things together and only with respect to those things. It is possible to imagine multiple, solitary individuals acting separately upon the landscape, never cooperating. They may even act in ways that are mutually advantageous. Yet there still would be no public there, as there is only individual volition not coordination among the collection of human beings.

Modern societies are composed of layer upon superimposed layer of publics and, as we will see, legal systems. Corporations are publics. Families are publics, as are churches, law faculties, school districts, and criminal gangs. Even two cooperating individuals engaged in 
traditional contracting are a public. ${ }^{7}$ All are self-consciously groups, and all have different processes that maintain the cooperative ties that define them, effectuating the purposes that draw their constituents together.

In contrast to the non-interactive, individual wills that characterise mere parallel collections of human beings, or non-publics, law is the name we give to the process (and there is always a process, however changeable) by which a public realises its shared purposes through the management of a set of coercive resources. Such resources always exist where cooperation is present, because coercion is implicit in cooperation itself. If two humans cooperate, there is always the risk that cooperation will be discontinued. That minimal inducement is all we need to observe that cooperation is implicitly laden with conditions. Even so, the cooperative enterprise may be, and usually is, more complex, with additional means beyond defection to ensure continued participation. For example, if the reason collaborators continue their cooperation is that one has threatened the other with violence, then the coercion is plain. ${ }^{8} \mathrm{~A}$ public, by definition, engages in processes to effectuate joint purposes, and these processes necessarily include among them management of coercive resources.

Every public, therefore, has a legal system, and every legal system belongs to a public. ${ }^{9}$ The concept of law and the concept of a public are inseparable, one yielding the other. Groups of humans, again, may belong to multiple, interacting publics and therefore be governed by multiple, interacting legal systems. This is intuitively obvious, as we find ourselves governed by family rules, local laws, state and national laws, rules of the workplace, and the like.

This identification of law with the management of a public's coercive resources, the threats a public can make in order to foster cooperation, is so natural that it has been central, at least implicitly, to a diverse array of theoretical approaches to the concept of law. The simplest positivist model, conceptually, is probably Austin's, which characterises law as comprising the commands of a sovereign backed by threats. ${ }^{10}$ The same type of approach is implicit in

7 Contracting parties in a public that will enforce the contract may also form what I will define as a 'private institution.' But the definition of 'private,' in the sense of the public/private theory, is dependent on the existence of a public. Without a public, there is no private entity, only an isolated one. Whether or not cooperating parties are recognised as a private institution within a larger public, they also form their own public.

8 I do not assume that the form coercion takes is a specific consequence expressed in advance in a written law. It may not be specified in advance. It may not be written. And even if coercive acts are specified - a fine or imprisonment, say - the coercive effect may extend to unspecified stigma accompanying the specification or even to the personal disappointment a violator may feel. The so-called internal point of view of an actor who takes at least some laws as reasons in themselves to conform his or her conduct can thus be taken into account. The public's social glue is maintained, in such instances and such individuals, simply by announcing a rule, which announcement is a threat, as breaking the rule would be personally undesirable to the actor.

9 We might reserve the term 'legal system' for law that has been organised into a predictable and manageable set of principles and procedures developed before disputes arise. That is, a legal system might only exist when law, the process, is purposefully managed. The existence of a system, though, does not imply selfconscious management of a process. I would call the process that is the law of a public a legal system even if one can only appreciate its existence from the external point of view - even when there is no internal point of view that understands there are standards of conduct.

10 John Austin, Lectures on Jurisprudence or the Philosophy of Positive Law, Robert Campbell (ed.), third edition (London: J. Murray, 1869), pp. 88-106. Austin's model is in part a restatement of ancient theory. 
Blackstone's great work, which described law as 'rule[s] of civil conduct prescribed by the supreme power in a State, commanding what is right, and prohibiting what is wrong., 11

For Oliver Wendell Holmes, legal duties were 'nothing but a prediction that if a man does or omits certain things he will be made to suffer in this or that way by judgment of the court. ${ }^{, 12}$ Even as Holmes wrote against the idea that the acts of legislatures or the writings of judges established and reflected a separate, formal system of rules, he acknowledged as a premise that a public's legal system is efficacious on account of its ability to gain cooperation through the threat of unpleasant consequences.

Holmes' account is a significant refinement of Blackstone's model, which assumes a 'supreme power' and so fails to capture the complexity of law in real societies. Focusing on the predictions of law's subjects rather than the supremacy of law's makers permits us to understand legal systems that feature even rampant non-compliance and those that operate within and among societies that have pluralistic and competing sources of rules. A public pursuing cooperation may take the form of a violent dictator demanding and obtaining absolute obedience, but it may only be a weak social aggregation among much stronger ones, providing only slight disincentives to defection.

This, too, is the view of Robert Cover. 'Legal interpretation is (1) a practical activity, (2) designed to generate credible threats and actual deeds of violence, (3) in an effective way.' 13 Cover was writing about formal legal systems like those of modern nation-states, but his insight is broader: that law is the name for the public's practical working out of the use of its coercive capacities, whatever they are, most often for maximum effect given all the public's competing values. ${ }^{14}$ Among law and economists, it is a given that 'the fundamental thing that law does is to decide which of the conflicting parties will be entitled to prevail. ${ }^{15}$

Even H. L. A. Hart, writing against the command theory, did not deny coercion's omnipresence in legal systems. In the Postscript to his Concept of Law, he stated: 'Legal rights and duties are the point at which the law with its coercive resources respectively protects individual freedom and restricts it or confers on individuals or denies to them the power to avail themselves of the law's coercive machinery. ${ }^{16}$ Coercion, Hart agrees, is law's ultimate action, even if not its purpose. The purpose of law, of course, is cooperation, and coercion and the threat of coercion are means a public has to achieve it. Law is the process

11 William Blackstone, Commentaries on the Laws of England, vol. 1 (Oxford: Clarendon Press, 1765), p. 44.

2 Oliver Wendell Holmes, 'The Path of the Law' (1997) 110 Harvard Law Review 991 at 992.

13 Robert M. Cover, 'Violence and the Word' (1986) 95 Yale Law Journal 1601 at 1610.

14 I will not here detail in depth the possible distinctions between 'legal interpretation' as Cover uses the term and 'the law' or 'legal systems' as I have used the terms. Cover refers to more than the judicial extraction of the semantic meaning intended by the authors of some text. He instead uses the term, like Ronald Dworkin, to describe the creation of meaning using texts, among other sources, as data, with the intention that these culturally constructed meanings yield definitive action. Such activity has a central place in the more general enterprise of law, which Cover says is 'the attempt to build future worlds.' Ibid. at $1602 \mathrm{n} 2$. See also ibid. at $1611 \mathrm{n} 24$ ('[T]he dominant form of legal thought ought to be interpretive in the extended sense of the term.').

15 Guido Calabresi and A. Douglas Melamed, 'Property Rules, Liability Rules, and Inalienability: One View of the Cathedral' (1972) 85 Harvard Law Review 1089 at 1090.

16 Hart, Concept of Law, 269. 
for managing such threats, even if they will, one hopes, usually provide guidance for right conduct rather than signals about the expected cost of non-compliance. ${ }^{17}$

All of these observations reduce, in their weakest forms, to an unremarkable assertion about human cooperation. When we engage in cooperation, we do so against a set of information about the consequences of defection. The ability to impose consequences inheres in the idea of a public as a set of cooperating people. It is the management of these coercive resources that is a legal system.

Thus far we have an understanding of what it is we aim to study but very little to help us understand it. In fact, in graphical form our model of legal systems looks like this:

\section{Conditions of coercion}

Yes, there is really nothing there other than the identification of a public with the management of coercive resources. To progress toward the institutional model, we need first a better, more realistic model of rules.

\section{Primary and Secondary Rules}

The analytical fulcrum across which Hart's Concept of Law shifted the meaning of positivism is the distinction between so-called primary and secondary rules. Hart taught that law cannot be conceived entirely as a set of commands backed by threats. A legal system cannot be accurately understood as a list of rules of behaviour paired with unpleasant consequences, providing coercion to comply. There are, inevitably, rules about such rules. Even a list of rules chiselled into a stone tablet is not, in itself, a complete legal system. To understand the system in which the tablet plays a part, we must understand the, perhaps unwritten, rules about the tablet's rules. For example, if the tablet's rules are truly authoritative, it is only because there is an additional rule that they are authoritative. This is an example of a secondary rule, a rule about a primary rule governing conduct. All systems possess such rules, and Hart established the impossibility of understanding a legal system without taking

17 As Hart puts it:

Since the occasions for legal coercion are mainly cases where the primary function of the law in guiding the conduct of its subjects has broken down, legal coercion, though of course an important matter, is a secondary function. Its justification cannot be sensibly taken to be the point or purpose of the law as such.

Ibid., 249. I believe Hart's insight - that law's function is to signal expected conduct to people who will take the law's existence as a reason to conform their conduct - is correct in many applications. But the carrier signal for this information is coercive threat, the if-then formulation of a standard of conduct and consequence of defection. To understand the practice of law and a society's use of the law it makes, it is of course necessary to appreciate the internal points of view of the participants, many of whom take law as a signal, not a threat. The way the if-then language of law, to the extent the legal system under consideration even operates by ex ante rules, is taken up by members of the public will be relevant to the crafting of laws and remedies. But we need not assume anything about this in order to arrive at the public/private institutional model I will develop. The application of that model, though, certainly does depend on more specific information about the culture in which the legal system is embedded. 
account of them. The law, he says, is the union of primary rules of behaviour and secondary rules of recognition, change, and adjudication. ${ }^{18}$

But the pathway to this simple and elegant conception of law had already been blazed by Wesley Newcomb Hohfeld. ${ }^{19}$ Hohfeld is almost always cited for having established a framework of basic, jural opposites and correlatives, the citation usually only making the general point that all law is relational in the sense that affecting A's rights necessarily affects someone else's duties. Hohfeld composed an eight-element periodic table of legal relations and two forms of relations (opposition and correlation) among them. His elaboration is more ornate than necessary and his discussion unfocused by modern standards. But the Hohfeldian framework is ingenious, powerful, and ultimately very easy to understand.

There are two basic concepts: (1) law's action is always relational, that is, between one entity within the public and another (often one individual against another), and, (2) legal rules are of two types: primary (duties) and secondary (powers). Primary rules concern the conditions for the application of public coercion. Secondary rules concern the authority to make (and thus change and repeal) primary rules.

First, Hohfeld teaches that whatever its system for recording rules and explicating them, law's action occurs when a public actually deploys the coercive powers it possesses. He does not say this directly, but it is implicit in his scheme. A duty has no meaning apart from a correlative right. ${ }^{20}$ That is, to have a duty means that there is another member of the public with the authority to ask the public to coerce its performance. In this way, an understanding of a public's law is built from the ground-up as the larger story of the pair-wise results of contested, if mostly hypothetical, calls for public coercion, or cases in the usual manner of speaking.

Although described by Hohfeld as fundamental, the first four legal relations - rights, duties, privileges, and no-rights - are all derivative of the primitive concept of a duty imposed by a public. If one has a duty with respect to some other entity, then that entity has a right, in the sense that the entity can compel the public to coerce the duty holder into compliance. If one does not have a duty with respect to some conduct, then he or she is privileged and no person has a right to stop the conduct. To have a no-right is to have no ability to enforce a duty that would proscribe the conduct. ${ }^{21}$ Thus, from the basic concepts of public and duty, the other relations can be deduced. There is duty and its absence. There is the ability to call for the enforcement of a duty and the absence of such an ability.

This first part of Hohfeld's analysis could be read as a comfortable amendment to the command theory. Law is indeed a set of rules backed by threats, but the rules are necessarily relational, meaning they are always either enforceable, or not, by some entity. What I characterise as the second part of Hohfeld's analysis is less amendment and more remaking of that theory. Here, Hohfeld established a legal concept distinct from duty: 'power'. One

18 Ibid., 94-9.

19 Wesley Newcomb Hohfeld, 'Some Fundamental Legal Conceptions as Applied in Legal Reasoning' (1913) 23 Yale Law Journal 16.

20 Ibid. at 30-2.

21 Ibid. at $32-44$. 
who has a power in a public has the authority to create an enforceable duty on another member of the public. ${ }^{22}$

As with duty, power alone generates the other three legal relations. Definitionally, power has an object - some entity or entities on whom the empowered entity can place a duty. One who is subject to such a power has a liability, and one who is not is immune. The absence of power is disability. ${ }^{23}$

Hohfeld has thus identified not eight fundamental relations but two fundamental concepts: duty and power. To put it in other terms, Hohfeld defined a legal system as the union of primary rules (the contents of duties) and secondary rules (the contents of powers) governing the public's coercive resources. Corbin's defence of Hohfeld fits even more nicely with the model under development. Hohfeld's central question, for Corbin, is whether 'the cumulative strength' of 'the multitude of ... citizens who constitute ... 'the state',' which Corbin personifies as a giant, can or cannot be called upon to aid an individual. ${ }^{24}$ All of Hohfeld's relations, Corbin explains, are derived from the question whether an individual can call upon the giant's help, enforcing a right, and the question whether an individual can influence the giant's actions, wielding a power. The entire frame assumes that at least the hypothetical coercion of a public is the very thing that law concerns.

What I wish to emphasise here is not that Hohfeld is the original author of some of the major ideas in The Concept of Law, which contains a much richer explanation of the virtue and nature of both secondary rules and rules in general, but that the very idea of human beings cooperating and thus forming a public necessarily includes the concepts of duty and power. To find a collective of human beings operating in a concerted way, rather than in parallel, is to find them operating conditionally. All cooperative enterprises have terms. Perhaps these terms are only the conditions of further cooperation. Perhaps they are conditions under which violence by one or more members will be withheld. Perhaps they are written. Perhaps they are unwritten. But wherever there is cooperation, there is not only coercion, but a union of primary and secondary rules governing that coercion.

Hohfeld also helps us to appreciate that the management of coercion concerns the resolution of pair-wise conflicts (so long as one element of the pair is understood sometimes to be a representative of larger segments or perhaps all of the public). If the society is cooperating, rather than acting individually, we should be able to detect that fact in at least the hypothetical resolutions of such conflicts. If no conflicts are even hypothetically possible, then there is no interaction, and we have human beings acting in parallel on the landscape, not as a public.

When the public resolves a conflict, it takes up a claim that some entity has made against another. (Again, if no one makes a claim that the public should use coercion, then there is no conflict.) The public then decides whether to apply some of its coercive resources by consulting its laws. We need assume no particular structure here. This adjudication could involve the reading of ancient tomes, a Herculean exercise of fit and justification, or even a coin toss. The public must determine how it will decide who wins, how it will decide

22 Ibid. at 44. In Hohfeld's language, if a 'change in legal relations' may occur because of 'some superadded fact or group of facts which are under the volitional control of one or more human beings,' then those who have such volitional control have a 'power.' Ibid.

23 Ibid. at 44-58.

24 Corbin, 'Jural Relations', 228. 
whether to coerce an unwilling party. Thus, from Hohfeld, we see a distinction between the power to demand a public determination whether to coerce (the possession of a right) and the power to make the rules that will determine whether coercion will be ordered.

Hohfeld thus gives us this picture of a legal system:

\begin{tabular}{|c|c|}
\cline { 2 - 2 } \multicolumn{1}{c|}{} & $\begin{array}{c}\text { Rules concerning the } \\
\text { exercise of powers }\end{array}$ \\
\hline $\begin{array}{c}\text { Rules concerning the enforcement of } \\
\text { duties }\end{array}$ & Duties (conditions of coercion) \\
\hline
\end{tabular}

I call these sets of questions ones of prosecution (enforcement of duties) and lawmaking (exercise of powers, or the creation of duties). The next step toward a general understanding of legal structure is to observe the way in which a public must inevitably decide how to answer such questions. Here we find a world of information-generating institutions.

\section{Institutions and Information}

Publics are groups of people, and to the extent a public 'acts,' it does so through the actions of the people that compose it. Of course, humans undertake all sorts of actions. Only some of these actions refer to a public in which the actor is embedded. I may ride my bike to work, have a cappuccino at my local coffeehouse, and read to my children. Which of these is a 'public act,' depends on the processes governing the various publics of which I am a member.

An institution is a group within a public that generates information recognised as legally relevant by the public's secondary rules. A given group of people may at times and with respect to some actions be an institution in a public and at other times not. When my colleagues and I vote on faculty matters, we are an institution within the university. When we share food and drink afterwards, we are not that institution. This is a function of the secondary rules within the university that recognise the former but not the latter as the producers of information salient, ultimately, to the management of the university's coercive resources.

Because a public is not a group of people acting in parallel, but a cooperating group of people, it must communicate, in the form of information, intentions among its members. This is why the practice of law consists of a union of institutions and information. ${ }^{25}$ It is a process by which a public evolves, its members exchanging publicly salient information and acting on the basis of that information.

H. L. A. Hart's definition of law, the union of primary and secondary rules, is not wrong or even so much incomplete, as such. ${ }^{26}$ But without emphasising more explicitly the nature of law's practice, as an exchange of information among institutions, we have too static a picture of law as an abstract set of rules, like the instructions that accompany a board game (even if

25 A complete description of this theory would require grappling with the institutional and informational context of ultimate rules of recognition and, in general, greater analytical rigour. I leave this project for another day.

26 The recognition of institutions and their resulting information economy are, after all, consequences of Hart's secondary rules. 
they are supplemented by social practices that modify or amend the instructions). The practice of law is a dynamic, bustling zoo of institutions generating and consuming information. All of a public's law is contained in a self-referential and continuously altered set of information, whether one takes that information to be the diverse array of data that permits Holmesian predictions of judicial action or the Hart-like sources of signals that provide grounds for criticism of rule-breakers.

Consider a statute, an opinion, or an executive order. While coercion - which would include the acts of handcuffing, jailing, and seizing - is law's effect, the law itself is the information that officials use to decide what to do. A police officer who puts me in a squad car is not 'doing the law,' she is hopefully acting in accordance with the law, meaning consistently with the information the collective has generated regarding what actions its representatives will take in response to various events. Even the fact that the individual putting me in the car is a police officer, bearing some special status within the collective, is not a fact bound to the world. Rather, that individual has clothed herself in the official garb, has acted as if the universe of legal information justifies her actions, and has been treated by others as if she is doing what the collective wishes. If she is wrong about this, knowingly or not, the law will not approve her actions and may well provide information that others will rely on to punish her, by physically restraining her or forcing her to convey assets.

As Robert Cover puts it in his remarkable article, 'Violence and the Word':

The context of a judicial utterance is institutional behavior in which others, occupying preexisting roles, can be expected to act, to implement, or otherwise to respond in a specified way to the judge's interpretation. Thus, the institutional context ties the language act of practical understanding to the physical acts of others in a predictable, though not logically necessary, way. ${ }^{27}$

Cover teaches us that the institutional understanding of a legal system, if the system aims to be effective, leads naturally to normative criteria. 'The practice of interpretation requires an understanding of what others will do with such a judicial utterance and, in many instances, an adjustment to that understanding, regardless of how misguided one may think the likely institutional response will be. ${ }^{28}$ That is the power of an institutions and information approach to understanding legal systems: the fact that information has both an author and one or more audiences provides criteria of effectiveness that refer only to the processing capacities of the institutions involved.

I believe this to be the most important benefit of the public/private theory of legal systems. While I am attracted to the aesthetic qualities of its description (and the intuitions that seem to spring from it), its most critical feature is that it makes transparent that many questions that seem substantive and substance-area-specific are in fact questions of the competence of institutions to make and receive particular kinds of legal information. Before we deal with specifics, however, it is worth considering a bit more closely what sort of normative calculus we might derive from the institutional understanding of a legal system and Cover's insight concerning author and audience.

I suggest two guiding principles should and will very likely lurk behind a legal system's secondary rules governing institutions. ${ }^{29}$ What I call the first principle, or ex ante principle,

27 Cover, 'Violence and the Word', 1611.

28 Ibid.

29 See Turner, 'Law’s Public/Private Structure', 1033-4. 
requires that an institution's decision-makers be selected and empowered in a way that is likely to render them institutionally competent. By competent I mean that they act consistently with an optimisation of a social welfare function. The second principle, or ex post principle, mandates invalidation of legal information (usually laws) when that information manifests the incompetence of the institution that generated it. The claim of the institutional theory is that a great many specific rules of law can be deduced from these broad principles when applied to a specific institutional setting.

Further, I have advanced a set of discrete indicators, or types of competency, against which an institution's selection mechanisms, scope of authority, and informational output can be checked for compliance with the first and second principles. I derived them from a decomposition of a generic social welfare function. ${ }^{30}$ They are as follows: $:^{31}$

- Private calculation competency reflects the ability of an institution to estimate the preferences of others with respect to the decision at hand.

- Public calculation competency refers to the ability to assess that portion, if any, of the collective good not reflected in individual preferences.

- Aggregation competency is the ability of a decision-making entity to combine these preference inputs, weighing and ordering them, according to the collective will.

- A particular kind of aggregation competency is the ability to weigh the preferences of another as heavily as one's own. This capacity to decide unselfishly I call distributive competency.

- And finally, resource competency is the possession of the means actually to effect a decision.

Armed with these tools, it is possible to reflect on the decisions an institution will be asked to make and to design secondary rules to govern the institution so as to encourage competent decision-making and to review for incompetency ex post. It is also possible to compare institutions to determine their relative advantages at addressing a legal problem. But to do any of that we obviously need more information about the decisions at issue and the institutional possibilities.

While adding this institutional method has not altered the taxonomy of legal systems we derived from Hart and Hohfeld, some modifications to the chart make clearer how legal institutions relate to the primary rules that govern behaviour. I will call the set of secondary rules governing the making of primary rules 'Constitutional Law' and the set of secondary rules governing the prosecution of the violation of primary rules 'Procedure'. Using these new terms and adding spaces for the institutions regulated by these secondary rules, we have the following chart.

30 Ibid. at 1018-21. The basic idea is that any decision requires gathering inputs and computing an output. These inputs and the computation of the output can be broken down in the manner expressed here.

31 The description of the competencies is adapted from my article applying the public/private theory to the problem of state action. Turner, 'State Action Problems', 298. 


\begin{tabular}{|c|c|c|}
\hline & & Constitutional Law \\
\hline & & Lawmaking Institutions \\
\hline Procedure & Prosecuting Institutions & Primary rules (duties) \\
\hline
\end{tabular}

There is, however, still more that we can say before delving into the specifics of a particular working legal system. There is yet another inherent dynamic arising in any public that allows us better to see the structure of all legal systems and the basic templates of secondary rules. We now turn to the public/private distinction.

\section{The Public/Private Theory of Legal Systems}

Primary rules are as variable as the societies that create them. We can examine the rules of a collective and the culture of a collective to attempt to discover what the consequences of its rules might be. Does a rule prohibiting murder and imposing a given punishment effectively serve a goal of reducing the incidence of murder? How fast will people in a society drive automobiles if the law limits their speeds and provides a given array of penalties? The answers will depend on social context and any number of particulars concerning culture, funding, enforcement effort, and the like.

For the theorist, there is perhaps more immediate interest in wondering whether we can say more about the set of secondary rules in a society. How does a public make new primary rules or, for that matter, secondary rules? Are there limits to the kinds of rules it can or should make? Why? Are these rules as contingent on culture and as manifold as the myriad of possible primary rules, or do they inevitably deal with certain questions?

So far we have posited only a cooperating group of humans. From this assumption of cooperation, we have defined a public. That public necessarily realises cooperation through primary rules backed by threats of coercion. But to make, adjudicate and carry out this law, the public defines institutions that consume and generate the information that composes the system of primary and secondary rules, which ultimately manage the public's coercive resources. A legal system is, therefore, the name we give to the union of institutions and information created by a public, resulting in a set of primary and secondary rules. From Hohfeld and Hart, we know a little more about these secondary rules - that they govern both the creation of duties and the enforcement of duties.

The public/private theory of legal systems, initially, adds a single detail to the model we have derived from this bare assumption of cooperation. With this addition, the familiar structure and constraints of modern legal systems emerge. The detail that gives legal systems their familiar shape is indeed the often-maligned public/private distinction - but not the distinction in the general, vague sense that has left it so vulnerable to lawyerly attack. Rather, the specific use of these antithetical terms to describe the most basic character of the institutions that compose a legal system is what will make so much legal structure apparent as a mere consequence of our simple assumption of cooperation. 


\section{A What Does It Mean to Say That an Institution Is Public or Private?}

We have proceeded from the position that a public and a legal system are inseparable, a public being any cooperating group. All institutions within a public are in some sense 'public institutions' as they, by the definition above, are recognised by the legal system's secondary rules as informational participants. The public/private theory uses a finer institutional gradation than that between recognised institutions and unrecognised groups. ${ }^{32}$ We will therefore distinguish among a public's institutions, labelling some institutions as public and others as private.

The goal, following from the last section, is to develop a model of legal systems that is conducive to application of the two institutional principles developed in the last section. So, I ask whether there are, in all legal systems, fundamentally different types of institutions with respect to that institutional calculus. In short, yes. There are those institutions controlled by the public and those the public recognises but that are controlled by its members as individuals. It is to these types that I give the labels 'public' and 'private,' respectively.

The terms public and private are, in general, obviously ambiguous. They possess a great many senses. Private can mean, among many other things, secluded from the view of others, relating to the affairs of the family rather than the community, or concerning voluntary markets rather than government. As Jeff Weintraub writes, '[t]he public/private distinction, in short, is not unitary, but protean. It comprises, not a single paired opposition, but a complex family of them, neither mutually reducible nor wholly unrelated. ${ }^{33}$

My goal is not to delve deeply into the full range of activities we call private or public and the distinct but related reasons for which we use those terms. ${ }^{34}$ Rather, I distinguish legal choices made by or on behalf of a group from those the group leaves for its members. ${ }^{35}$ The distinction is between public and private agency, 'between an agent acting privately, i.e. on his own account, or publicly, i.e. as an officer of the city, community, commonwealth, state etc. ${ }^{36}$ To cabin the analysis further, I will not even ask whether an institution is public or private. Rather, we will ask whether specific institutional decisions - lawmaking and

32 Unrecognised groups are not part of the theory at all. Of course, such a group may form its own public, with its own legal system. That it is unrecognised means that none of its information-producing activities have legal significance in the public within which it is embedded. Its members are, of course, still regulated by the primary rules of that public.

33 Jeff Weintraub, 'The Theory and Politics of the Public/Private Distinction', in Jeff Weintraub and Krishan Kumar (eds.), Public and Private in Thought and Practice: Perspectives on a Grand Dichotomy (Chicago: University Of Chicago Press, 1997), p. 2.

34 While 'public' and 'private' are words each bearing many senses, they are more than symbols gathering under themselves homonyms for unrelated concepts. Each sense bears relations to the others, all stemming from what Stanley Benn and Gerald Gaus call a 'complex-structured concept.' Stanley I. Benn and Gerald F. Gaus, 'The Public and the Private: Concepts and Action', in Stanley I. Benn and Gerald F. Gaus (eds.), Public and Private in Social Life (London: Croom Helm, 1983), pp. 4-5. Though they would perhaps not simplify it in this way, I would argue that the shared kernel from which the different senses emerge is the distinction between 'togetherness' and 'separateness.'

35 The restriction to 'legal' choices here is intended to reflect that a private institution is one that generates information recognised by secondary rules. Groups that do not have this property are not institutions within the public's legal system.

36 Benn and Gaus, 'The Public and the Private', 9. Other than agency, Benn and Gaus identify 'access' and 'interest' as domains described by the concepts of public and private. 
prosecution - are made publicly or privately. ${ }^{37}$ Publicly made decisions are those directed by the collective's will as expressed in secondary rules establishing agency. Privately made decisions may well be influenced by collective norms, but they do not entail collective control.

I choose to compare these two types of institutions for a couple of important reasons. First, this coarse choice of institution - private versus any number of public ones - is the predominant, high-level categorisation that appears in our legal system and in many others. Second, it is a basic choice, in that a collective's very definition depends, essentially, on what powers it takes for itself. An essential question every collective must answer is under what circumstances it will stand behind the will of its individuals rather than assert a will of its own.

This coarse taxonomy of institutions has several theoretical virtues, even beyond its demonstrable utility. It mostly avoids a number of criticisms of the public/private distinction made by the legal realists and the critical legal theorists. And it elaborates on and advances the uses of the distinction by some of the very same scholars.

First, the taxonomy avoids any conclusion that what is left private in a society must be nonpolitical. $^{38}$ The distinction used here between private and public concerns only individual or collective control over a question. Private action, and not just in the aggregate, can surely have broad social impacts, to the point that such action can affect what it means to be a member of the collective. Choices influencing such meanings are public in effect, even if they are not publicly made.

The distinction I intend here does not divide law that ought to be policy-laden from that which is purely formal, as Morton Horwitz has argued was the goal of the relentless pursuit of a clean separation between private and public law in the nineteenth century. ${ }^{39}$ This would be simply impossible to achieve. For the reasons already mentioned, any system of private law will have distributive consequences. The famous scholars and scholar-judges of the early 20th Century attacked the public/private distinction for its attempt to hide this fact. ${ }^{40}$ What

37 Another choice, concerning remedy valuation, yields a possible third-dimension of the model that unifies the theory with the theory of property rules and liability rules.

38 Weintraub, 'Theory and Politics', 36.

39 Morton J. Horwitz, 'The History of the Public/Private Distinction' (1982) 130 University of Pennsylvania Law Review 1423 at 1425-6 ('What were the concerns that created a virtual obsession with separating public and private law, both conceptually and practically, during the nineteenth century? Above all was the effort of orthodox judges and jurists to create a legal science that would sharply separate law from politics.').

40 Ibid. at 1426; Robert L. Hale, 'Coercion and Distribution in a Supposedly Non-coercive State' (1923) 38 Political Science Quarterly 470 at 470-9. Soviet theorists attacked the public/private distinction for the same reason. E. B. Pashukanis argued that private law, as opposed to public administration, creates a Republic of the Market, which serves only to hide The Despotism of the Factory.

The judicialising of modern society was the work of the bourgeoisie and could not be carried out coherently: the bourgeoisie tended to privatise all law while yet needing public law to safeguard its position as a ruling class. The distinction between public and private was one of the (ideological) contradictions of capitalism: 'For us [the Soviets] there cannot even be a discussion of the limitation of state intervention in any sphere of economic activity — but this is the very first thing that follows from the division of law into two spheres.'

Alice Erh-Soon Tay and Eugene Kamenka, 'Public Law - Private Law', in Stanley I. Benn and Gerald F. Gaus (eds.), Public and Private in Social Life (London: Croom Helm, 1983), pp. 84-85 (citing E. B. Pashukanis, General Theory of Law and Marxism (Moscow: Sotsiahsticheskoi Akademii, 1924) and quoting 
anti-progressive judges called private, these scholars argued, often carried enormous public consequences, and thus should conform to broader public policies. ${ }^{41}$

That, however, is not my battle here. How a state decides the conditions for enforcement and the methods for enforcement of private law is a different and more complex question than the simple one I initially ask: what law of a group is primarily defined by individuals and what is primarily defined by the group? The focus here is only, for the moment, on identification of a category, not on how laws within each category should be drafted or regulated. That legislators have a tendency to favour incumbents when crafting election laws, for example, may be a reason for creating special rules to pass, to review, and to interpret such laws, but it does not make us doubt that public legislation exists. The category exists even if the laws within it are corrupt or unwise. Indeed, the distinction between public and private power to make publicly-backed law looms larger when private coercive power is thought to be considerable. In any event, the sculpting of secondary rules through which private parties may make agreements that result in public coercion should surely be sensitive to the political reality of private power. ${ }^{42}$ But that is an observation that relies on the distinction, not one that denies it.

The second critique of the distinction on which the model relies was most famously articulated by Duncan Kennedy. He raises the possibility that what is public and what is private are thoroughly and hopelessly indeterminate, that legal reality cannot be sensibly sorted by the criterion I propose. ${ }^{43}$ Using the public/private distinction as a mere example, he argued that any legal dichotomy worth fighting over will (a) eventually spawn intermediate categories, (b) collapse as each case comes to be seen as a hybrid, (c) devolve into balancing tests that weigh in each case the relative influence of the omnipresent poles, and (d) finally descend into brain dead litigation postures caricaturing the generic factors typical of every case in which the distinction is raised. ${ }^{44}$

The moral of this story, for it is not a legal history per se, is that the world is complex and efforts to paint it only in black and white will fail. Eventually reasonable people will point out all the grey staring them in their faces, and litigation will descend into intellectually insubstantial legal theatre in which grey is described, using standardised rhetoric, as black by one side and white by the other, but where everyone knows the game. Thus, Kennedy calls into question the sense of basing any serious analysis on the difference between the public and the private. ${ }^{45}$

E. B. Pashukanis and L. la Gintsburg, A Course on Soviet Economic Law (1935), p. 330 (brackets in original).

41 Horwitz, 'History', 1426. Horwitz also describes (at 1427) how the horrors of the totalitarian regimes of the mid-20th century sowed the seeds of retrenchment. Greater scepticism of regulating private affairs in order to achieve 'public' goals led to general acceptance of the idea that the state's role was to find accommodation between conflicting private interests, not to substitute a (potentially autocratic) public preference for those of the regulated individuals.

42 See, e.g., Hale, 'Coercion and Distribution', 493.

43 Duncan Kennedy, 'The Stages of the Decline of the Public/Private Distinction' (1982) 130 University of Pennsylvania Law Review 1349.

44 Ibid. at 1350-4.

45 A similar argument is made by Tay and Kamenka:

[T] he significance of distinctions between public and private law is not well brought out by semantic analysis or by a classificatory approach. Both of these, in the case of law, tend to smack of circularity or to run into considerable conflict between the theoretical interest in consistency and the enormous impact 
While this critique correctly describes the descent into formal game that befalls many brightline rules, the primary source of confusion in distinguishing public from private stems from the indeterminacy of the question asked, not any inherent defect in the terms themselves. For example, in a society in which publicly raised taxes are often combined with private funds to carry out projects, asking whether such a project is 'public or private' is an imprecise question, inevitably yielding an indeterminate answer. Even if one asks whether the project is 'publicly or privately funded,' the answer can do no better than to reflect the problematic fit of the question to the social reality.

A model based on the distinction should pose better questions. The questions of institutional control that I pose - who creates law and who can force its adjudication - are derived from the way I believe legal systems in fact do and inevitably must structure themselves and, in any event, are designed to produce answers of minimal ambiguity. 'If we are careful to avoid the trap of describing law or some practice as public or private in general and instead focus on whether a public or a private entity is the source of a particular decision, much of the perceived incoherency of the distinction falls away. ${ }^{46}$

The taxonomic concern of this chapter is only with how individuals representing themselves and institutions representing the collective make certain, discrete types of determinations. The distinction between such institutions is real, meaning that the public and the private really are different modes of decision-making. Coercion based on law devised by an individual for his or her own purposes invariably raises different issues than does coercion based on law created by the group at large for the public's purposes. The effort now is to discover the import of this fundamental difference.

\section{B The Public/Private Model of Legal Systems}

It is now possible to refine the model of legal systems by distinguishing public from private institutions. Primary legal rules may either be publicly or privately made. And the decision whether to adjudicate an alleged violation of a primary legal rule (the power to force the collective to apply primary rules to determine whether to apply its coercive resources) may either be publicly or privately made. This observation refines the chart at which we had arrived after introducing the institutional theory, as now we have two basic types of institutions, public and private, that may make lawmaking and prosecution decisions and which are governed by Constitutional Law and Procedure, respectively.

Those primary rules that are privately made and privately prosecuted, I call Contract Law. Those that are publicly made and privately prosecuted, I call Tort Law. Publicly prosecuted and publicly created rules are called Criminal Law. A rather odd category also appears in the model: privately made but publicly prosecuted rules. I call this last category Parens Patriae (the name often given to such suits as, for example, the public enforcement of the terms of a private charitable trust). The public/private model of legal systems is now complete.

of historical accident and peculiarity on the actual development of legal systems. Classificatory approaches are forced to recognise the existence of mixed forms and though they can do so without overt contradiction, such recognition does not help to illuminate the reasons for the mixture, the nature of the conflict or the character of legal trends. A far better approach is to think of private and public law in terms of conflicting paradigms or ideal types, representing internally coherent and externally conflicting logical trends or 'moments' within the law.

Tay and Kamenka, 'Public Law - Private Law', 83.

46 Turner, 'State Action Problems', 304 (emphasis in original). 


\begin{tabular}{|c|c|c|c|}
\cline { 3 - 4 } \multicolumn{2}{c|}{} & \multicolumn{2}{c|}{ Constitutional Law } \\
\cline { 3 - 4 } \multicolumn{2}{c|}{ Procedure } & Privately Created & Publicly Created \\
\hline \multirow{2}{*}{\multicolumn{1}{c|}{}} & $\begin{array}{c}\text { Privately } \\
\text { Prosecuted }\end{array}$ & Contract Law & Tort Law \\
\cline { 2 - 4 } & $\begin{array}{c}\text { Publicly } \\
\text { Prosecuted }\end{array}$ & Parens Patriae & Criminal Law \\
\hline
\end{tabular}

An exploration of some of the consequences of conceiving legal systems this way reveals the simplifying power of the model.

\begin{abstract}
By creating a substantive map of legal systems in terms of institutional control over basic decisions, we can (1) understand apparently substantive problems in institutional terms and (2) translate problems and results from one substantive area of law to another by noting and adjusting for the different institutional environments. ${ }^{47}$
\end{abstract}

For example, both public and private Constitutional Law contain rules for lawmaker selection, law passage, and rights protection. The model gives us a unified way to think about these problems - how, for example, the rules governing contract formation and enforcement arise from the same principles as the rules for the creation and enforcement of torts, but refracted through a different institutional environment. As Hart wrote, 'many of the features which puzzle us in the institutions of contract or property are clarified by thinking of the operations of making a contract or transferring property as the exercise of limited legislative powers by individuals. ${ }^{, 48}$

\title{
C The Institutional Calculus and the Public/Private Theory of Legal Systems
}

The first (ex ante) and second (ex post) principles of institutions in combination with the core competencies (private preference calculation, public preference calculation, aggregation, distributive, and resource) provide a way to analyse and to compare institutions tasked with various types of decisions. They can be applied here to analyse the relative capacities of and needed regulations on public and private lawmakers and prosecutors. Put differently, the first and second principles generate many of the more specific rules of Constitutional Law and Procedure.

Recall that the first principle requires that an institution be composed and empowered in a way likely to render it institutionally competent, in the sense that it exhibits all of the core competencies. This principle will, for example, provide constraints on rules of lawmaker selection and limitations on a lawmaking body's scope of authority. The second principle requires invalidation of a decision that manifests the incompetence of the institution that reached it. For example, a law may be invalidated when a first-principle-compliant lawmaking body passes a law that is, say, so harmful to the interests of others that it manifest the unequal weighing of their interests in the decision (a failure of the distributive competency).

\footnotetext{
47 Ibid. at 295.

48 Hart, Concept of Law, 96.
} 
I have elsewhere analysed the core competencies as they apply to public and private institutions in greater detail, ${ }^{49}$ but a sketch and some examples can illustrate the possibilities of the theory. Consider the conditions under which private parties should be permitted to enact laws binding on others.

It is typically assumed that individuals know their own preferences better than others. That is, they maintain a private calculation advantage over others, including public agents. But aside from circumstances in which we expect self-interest to be muted, ${ }^{50}$ individuals are not typically distributively competent, meaning that they are likely in reaching a decision to weigh their own preferences more heavily than others' even if they properly calculate them. This incompetency provides a general ground, under the first principle, not to recognise privately made rules as binding on others. If there are to be privately made laws, they must be made under circumstances in which the private lawmakers are not likely to be distributively incompetent.

The solution is to insist on unanimity among those who will be bound by the privately created duties that result. A private group that can signal that it is, collectively, distributively competent and well-calculating may satisfy the first principle. If the group manifests through agreement that it will be better off with a law that imposes duties only on its consenting members, many societies will enforce the law, on the grounds that individuals are superior to others at knowing their own preferences and that a law that makes some people better off and no one else worse off is desirable (meaning that that the group is aggregatively competent as to such laws). Thus, a consenting group of private lawmakers proposing to bind only itself has all the core competencies and satisfies the first principle. $^{51}$

Public institutions, in contrast, make laws that are binding on those who do not necessarily consent to be bound. A welfare-oriented society, one concerned with the private preferences of its members, will maintain Constitutional Law that selects members of a public lawmaking body in a manner that maximises the body's potential to take account of the preferences of the individuals it will bind (private calculation competency) and minimises the possibility of self-dealing or favouritism at odds with public norms (distributive and aggregative competency). Such secondary rules, which we might gather under an umbrella term like

49 Turner, 'Law's Public/Private Structure', 1016-32.

50 For example, the public is highly deferential to the rules parents make for their children. See, e.g., Prince v. Massachusetts, 321 US 158, 166 (1944) ('It is cardinal with us that the custody, care and nurture of the child reside first in the parents, whose primary function and freedom include preparation for obligations the state can neither supply nor hinder.')

51 The theory also explains why different types of private laws often require different levels of evidence of consent. In 'Law's Public/Private Structure', I discussed the greater evidentiary requirements for wills, the very loose requirements for gifts, and the requirement that covenants 'touch and concern' the land before their obligations will be found to 'run' to non-party successors-in-interest. Turner, 'Law's Public/Private Structure', 1036-8. See also Turner, 'State Action Problems', 310:

[W]hile a current landowner is not particularly likely to be a good calculator of the preferences his successor will have generally, he may be better when it comes to preferences concerning the use of the land, as to which he and the successor will be more similarly situated. In addition, it provides some comfort that when it comes to enacting land-specific obligations, the current owner will be more likely actually to satisfy the preferences of successors when he must shoulder the same obligations and personally suffer any diminished property value in exchange for the benefits the covenant regime provides. As to these preferences, he is reasonably likely to be a good agent, whereas we would assume no such competence in binding successors to arbitrary contractual arrangements that do not primarily concern the important asset the covenanting parties and his successors have in common. 
procedural due process, are often rule-like and can be individually tied to securing the core competencies. $^{52}$

The important observation is that lawmaker selection rules have the same goals in both the Constitutional Law of Contract (in which standards of consent, usually in the form of offer and acceptance, are the key paradigm) and in public Constitutional Law (in which agencypolicing rules are the paradigm). The consent-related doctrines of private Constitutional Law are twins of the procedural due process doctrines of public Constitutional Law.

The structural rules that flow from the first principle are mirrored by the rights-protecting provisions generated by the second, or ex post, principle. The second principle demands that we scrutinise lawmaking output for institutional failure. For example, 'contracts manifesting unusually poor private calculations or tort or criminal laws demonstrating peculiarly poor public calculations or unusually bad distributive consequences will, at some point along the spectrum, be deemed to go too far and will not be enforced. ${ }^{53}$ Here, we again find twin doctrines, unconscionability and related doctrines within private Constitutional Law and substantive due process and related doctrines (including more specific provisions like equal protection and speech rights) within public Constitutional Law. ${ }^{54}$

\section{Applications}

I have only begun to explore the possibilities of the public/private theory. In 'Law's Public/Private Structure', for example, I analysed the application of the first principle to the Procedural dimension of the model to understand the appropriate substantive line between Tort Law and Criminal Law. ${ }^{55}$ The resulting analysis demonstrates the justifications for qui tam actions, ${ }^{56}$ for restricting punitive damages in Tort claims to low-multipliers of compensatory damages, ${ }^{57}$ and for permitting a private-party to pursue criminal-like sanctions against a spouse for the violation of a protective order intended solely for her benefit. ${ }^{58}$ Each of these substance-specific questions can be understood as an institution-specific application of the general principles of the model.

In another work, I used the theory to construct a principled state action doctrine, the doctrine in U.S. law that evaluates whether a formally private actor should be treated as the state and put to constitutional scrutiny. ${ }^{59}$ The famous case of Shelley v. Kraemer, ${ }^{60}$ in which the only state involvement was the judicial enforcement of racially restrictive private covenants that purported to run with the land, has proved exceedingly difficult to justify. The public/private theory reveals that the problem facing a court in such situations is not whether to apply Constitutional Law but which body of Constitutional Law to apply - the private Constitutional Law of contracts and covenants that insists mainly on consent or the public Constitutional Law of equal protection and due process that insists on good agency.

\footnotetext{
52 Turner, 'Law's Public/Private Structure', 1039-40 (citing and discussing Adrian Vermeule, 'The Constitutional Law of Congressional Procedure' (2004) 71 University of Chicago Law Review 361).

53 Turner, 'Law’s Public/Private Structure', 1042.

54 Ibid. at 1042-4.

5 Ibid. at 1045-64.

6 Ibid. at 1056-7.

7 Ibid. at 1058-60.

8 Ibid. at 1060-4.

59 Turner, 'State Action Problems'.

60334 US 1 (1948) ('Shelley').
} 
[T]he legal constraints on contracting parties are tuned to the problems private lawmakers typically encounter. Some acts of private lawmaking are, however, far more like public lawmaking, for which there are different types of constraints addressed to the stereotypical problems that attend making laws that bind non-consenting others. Private actors engaged in the equivalent of public legislation therefore present a state action problem, meaning that they are poorly governed by the usual private secondary rules. $^{61}$

The public/private theory, and the institutional perspective more broadly, led naturally to a two-step state action test that explains why the U.S. Supreme Court was correct to strike down the racist covenants in Shelley. The key to the theory is the observation that the problem concerns the selection of alternative bodies of Constitutional Law tuned to the basic institutional types: public and private. And when a private actor gains the equivalent of lawmaking power over others, as in Shelley where the cabal of private owners was able to use the doctrine of running with the land to enact the equivalent of racist zoning laws, it is up to the other public institutions, preferably legislatures but perhaps ultimately courts, either to restrain the actor altogether or to import agency-policing provisions of public Constitutional Law into the system of secondary rules governing the powerful private actor.

There is much more to do. The theory has applications to international regimes, in which the public is a community of nations and the members of the public are self-interested nationstates. Contract Law within such a regime would be represented by treaties and Tort Law by public international law enforceable by individual states. Viewing international law in this way reveals that supposed analogies to domestic law are in fact much more. The similarities of the regimes owe to their both being undergirded by the same public/private template, subject to the same institutional competency principles. And so, consent, standing, due process: all these should have roles in communities of nations similar to their roles in municipal legal systems. Moreover, the public/private theory provides a framework for evaluating how the systems might differ, perhaps, on account of the more sophisticated and corporate nature of the individuals that compose the public of nation-states, but also might be surprisingly similar owing to the inherent self-interestedness of both nations and individuals.

\section{Conclusion}

Legal theorists' efforts of the last hundred and fifty years to paint a more realistic picture of law's practice have at times embraced, at times rejected, and at times simultaneously embraced and rejected the notions of public and private. From diverse approaches, however, a straight line emerges from the pre-Austinian world of law as lists of commands issued by an authoritative sovereign to the generic public/private atlas and institutional calculus that can provide routes to understanding even the loosest of legal regimes. Our society is a multitiered mosaic of publics, each with its own legal system, embedded in complex ways among one another. The coercive order emanating from the Tort Law of a private workplace is sometimes enforceable under the Contract Law of a state. A nation itself can be under a Contract obligation (a treaty within the public of a community of nations) not to enact a Criminal Law (within its municipal legal system governing the public of individuals that compose the nation). That so many levels of government and society can be understood as operating under the same template presents a potent opportunity better to understand the pluralistic world we all inhabit.

$61 \quad$ Ibid. at 285. 